\title{
Nationalism and Islam: perspective of Egyptian and Syrian Muslim intellectuals
}

\author{
Muhamad Ali \\ University of California, Riverside \\ E-mail: muhamadali74@yahoo.com
}

\begin{abstract}
The problem of the relationship between nationalism and Islam has historically revealed dynamic discourses, but seems to have gained little attention. This problem is important not only in understanding the modern discourse on Islam and nationalism but also in promoting a dialogue between Islam and the West. This paper attempts to show how the best known of Muslim intellectuals from Egypt and Syria during the 19th and first half of the 20th century, managed to fuse Islamic concepts and nationalism together into a single, unified discourse. This paper approaches the question in two different ways. In order to provide a context, the first section reviews how nationalism emerged and influenced the Muslims. The next section studies how Muslim intellectuals have responded to foreign ideas in general and nationalism in particular, and how some of them have attempted to work out a compromise between nationalism and Islam.
\end{abstract}

Masalah hubungan antara nasionalisme dan Islam secara historis mengungkapkan wacana dinamis, tetapi tampaknya telah mendapatkan sedikit perhatian. Masalah ini penting tidak hanya dalam memahami wacana modern Islam dan nasionalisme, tetapi juga dalam mempromosikan dialog antara Is- 
lam dan Barat. Tulisan ini mencoba untuk menunjukkan bagaimana intelektual Muslim ternama dari Mesir dan Suriah pada paruh ke-19 dan awal abad ke-20, berhasil memadukan konsep-konsep Islam dan nasionalisme bersama-sama menjadi satu wacana. Makalah ini mendekati persoalan ini dengan dua cara yang berbeda. Dalam rangka memberikan konteks, bagian pertama mereview bagaimana nasionalisme muncul dan mempengaruhi umat Islam. Bagian berikutnya mempelajari bagaimana intelektual Muslim telah merespon ideide asing pada umumnya dan nasionalisme pada khususnya, dan bagaimana beberapa dari mereka telah berusaha untuk bekerja untuk mengkompromikan antara nasionalisme dan Islam.

Keywords: Nationalism; Islam; Intellectuals; Modernity

\section{Introduction}

In the Western discourse of modernity, there are several different perspectives on the relationship between nationalism and religion. First of all, nationalism and religion are different and contradictory. In this view, nationalism is assumed to be secular and inherently contradictory to religion. ${ }^{1}$ Secondly, the rise of nationalism coincided with a decline in the hold of religion. Religions lost power when confronted with the consciousness of a common nationality. ${ }^{2}$ Thirdly, nationalism took the place of religion as the principle which governs all social and intellectual life. ${ }^{3}$ Lastly, the imagined communities of nations do not replace religious communities, albeit the latter was in decline. ${ }^{4}$ The question can be asked as

\footnotetext{
${ }^{1}$ Peter van der Veer and Hartmut Lehmann (eds.), Nation and Religion: Perspectives on Europe and Asia, Princeton: Princeton University Press, 1999, 3.

${ }^{2}$ Rupert Emerson, From Empire to Nation: The Rise of Self-Assertion of Asian and African Peoples, Cambridge: Harvard University Press, 1960, 158; as also quoted in Abdullah alAhsan, Ummah or Nation: Identity Crisis in Contemporary Muslim Society, Wiltshire: Cromwell Press Ltd., 1992, 23.

${ }^{3}$ Anthony Smith, Theories of Nationalism, ondon: Duckworth, 1983, 21, as quoted by Fred Halliday, "The perils of community: reason and unreason in nationalist ideology", Nations and Nationalism, Vol. 6, No. 2 (2000): 157-8.

${ }^{4}$ Benedict Anderson, Imagined Communities, London: Verso, 1991, 22.
} 
to how Muslim intellectuals have viewed the Western ideas in general and nationalism in particular.

In fact, the question of the relationship between nationalism and Islam has historically revealed dynamic discourses, but seems to have gained little attention. ${ }^{5}$ This question is important not only in understanding the modern discourse on Islam and nationalism but also in promoting a dialogue between Islam and the West. This present paper attempts to show how the best known of Muslim intellectuals from Egypt and Syria during the 19th and first half of the 20th century, managed to fuse Islamic concepts and nationalism together into a single, unified discourse. This paper approaches the question in two different ways. In order to provide a context, the first section reviews how nationalism emerged and influenced the Muslims. The next section studies how Muslim intellectuals have responded to foreign ideas in general and nationalism in particular, and how some of them have attempted to work out a compromise between nationalism and Islam.

\section{Rise of nationalism in the Muslim world}

Before anything else, it is necessary to define what nationalism means. Nationalism (qawmiyyah) refers to a feeling, an idea, or a movement of being part of, or for the sake of, a nation (qawm, people). Related to this is patriotism (wataniyyah), which can be defined as a feeling, or an idea of being part of or for the sake of a country (watan, fatherland). In other

\footnotetext{
${ }^{5}$ Probably, the question of nationalism and Arab, rather than that of nationalism and Islam, has preoccupied most scholars. As for Arab nationalism, the old narrative which was formulated in the 1950s and 1960s when Arab nationalism reached its very momentum, and the new narrative, which evolved in the 1970s and 1980s when Arab nationalism was in retreat, have in large dealt with social, political, and intellectual history of nation and religion. See Israel Gersoni, 'Rethinking The Formation of Arab Nationalism in the Middle East, 1920-1945', in James Jankowski and Israel Gersoni (eds.), Rethinking Nationalism in the Arab Middle East, New York: Colombia University Press, 1997, 5-25.
} 
words, nationalism is love of a nation, while patriotism is love of a fatherland. ${ }^{6}$ Yet, many Muslims often use these two terms interchangeably.

As for the attachment of the 'religious' and the 'secular' to nationalism, some scholars have used the two terms to indicate significant difference between the two. Religious nationalism refers to a nationalism which is, strongly or weakly, implicitly or explicitly, related to a religion. Meanwhile, secular nationalism means that a national feeling is purely free from something religious, divine, or transcendent.

Originally, nationalism first developed in Western Europe, bringing about the reorganisation of the Europe in the 19th and 20th centuries. In the first half of the 19th century, it was associated with democracy and liberalism with its greatest 'prophet', Giuseppe Mazzini (1805-72). In the later 19th century, it was linked to aggressive, intolerant forms identified with military and trade rivalries, national expansion and imperialism. In the 20th century, it has been an essential element in fascism and other totalitarianisms. An association of nationalism and the nation-state began to appear at Napoleon's attempt in Europe. ${ }^{7}$

The Treaty of Westphalia (1648) was regarded by many scholars to signal the consolidation of the modern nation-state, secularism, and liberal capitalistic democracy.8 Nationalism as a political ideology, which evolved in Europe, was incorporated into European secularism. Thus, in this view, separation between the Church and the State was the most significant development in the relationship between nationalism and religion in Europe.

In Muslim countries, nationalism came and developed through the different, but related processes of foreign occupation, internal disinte-

\footnotetext{
${ }^{6}$ Cleveland, William L, The Making of An Arab Nationalist: Ottomanism and Arabism in the Life and Thought of Sati al-Husri, Princeton: Princeton University Press, 1971, 92-3.

${ }^{7}$ Allan Bullock and Stephen Trombley (eds.), A New Fontana Dictionary of Modern Thought, London: HarperCollins Publishers, 1999, 561-2, Roger Scruton, A Dictionary of Political Thought, London: Macmillan, 1996, 369.
} 
gration, and political modernisation. Napoleon Bonaparte's conquest of Egypt in 1798, the British occupation of Egypt in 1882, and the final collapse of the Ottoman Empire in 1924, marked the breakdown of the Muslim umma, or Muslim community, ${ }^{9}$ which resulted in a political and cultural gap between Europe and the Muslim world on the one hand, and Muslim disunity into separate entities on the other. ${ }^{10}$

In its early stages, nationalism in the Muslim World received the support of European powers for it was related to European liberalism, but in later stages it was largely anti-colonial nationalism after the Muslim lands had been occupied. ${ }^{11}$ To put it another way, nationalism in the Muslim world was at large a negative nationalism, that is to say a drive to eject alien control. The struggle for independence in Egypt, Iraq, Iran, Turkey, Transjordan, Syria, Palestine and Lebanon from the interwar era to the end of World War II represented a good example of this negative nationalism. ${ }^{12}$

${ }^{8}$ Hans E.Tutsch, Facets of Arab Nationalism, Michigan: Wayne State University Press, 1965, 49; Daniel Philpott, 'The Religious Roots of Modern International Relations', World Politics 52 (January 2000): 206-45.

${ }^{9}$ See Charles Wendell, The Evolution of the Egyptian National Image: From its Origins to Ahmad Lutfi al-Sayyid, London: University of California Press, 1972,78-80.

${ }^{10}$ Jamel Mohammed Ahmed, The Intellectual Origins of Egyptian Nationalism, London: Oxford University Press, 1960, 1.

${ }^{11}$ Various nationalisms have emerged in the world history. First, liberal nationalism as the classic form of European liberalism, dating back to the French Revolution, fusing the struggle for national independence and unification with the demand for limited and constitutional government. Second, conservative nationalism concerned with the promise of social cohesion and public order embodied in the sentiment of national patriotism. Third, expansionist nationalism which has an aggressive, militaristic, and expansionist character. Fourth, anti-colonial nationalism which draws inspiration from the struggle against colonial rule. This latter is the type of nationalism in developing world including the most parts of the Muslim world. See Andrew Heywood, Politics, Basingstoke: Macmillan, 1997, 109. 17; Majid Khadduri, Political Trends in the Arab World: The Role of Ideas and Ideals in Politics, London: The Johns Hopkins Press Ltd., 1970, 26-7.

${ }^{12}$ William L Cleveland, A History of the Modern Middle East, Colorado: Westview Press, Inc., 1994, 161-255. 
Meanwhile, the political, military, economic, social, and cultural dominance of Europe throughout the Middle East was practically almost inevitable. In the process, the concept of traditional division between dar alharb (the house of war) and dar al-Islam (the house of Islam) was undermined. ${ }^{13}$ Likewise, the conception of the dhimmis, or protection of nonMuslim minorities, and the millet system of the Ottoman caliphate began to be challenged. In addition, in some parts of the Middle East, Muslim law (shari'a) disappeared or became modified. In the late Ottoman era, a political secularisation started to prevail. The following two articles in the political program of the Turkish Committee of Union and Progress in 1911 revealed this process of transformation toward political secularisation.

Article IX. Each citizen without distinction of race or of religion will have right or equality and complete liberty and will be subject to all duties. All Ottomans are equal before the law... Article XI. Freedom to practice the religion known in Empire and the enjoyment of religious privilege accorded to different nationalities will be maintained. ${ }^{14}$

It should be noted that the Arab nationalist movement for separation and independence from the Ottoman Empire during 1908-1916 was not identical in motivation and ideology with the anti-Western nationalist movements after $1882 .{ }^{15}$ During the period of the late Ottoman Empire, Ottomanism and Turkish nationalism sprung into existence. It was after World War I that, along with the imposition of state boundaries by European mandatories, the Middle East in general entered the age of anti- colonial nationalism.

${ }^{13}$ Charles Wendell, The Evolution of the Egyptian National Image: From its Origins to Ahmad Lutfi al-Sayyid, London: University of California Press, 1972, 78-80.

${ }^{14}$ Charles R.Watson, "Nationality and Islam", The Muslim World, vol. 16, no.2, (1926): 124.

${ }^{15}$ Kemal H. Karpat (ed.), Political and Social Thought in the Contemporary Middle East, London: Frederick A. Praeger, Inc., 1968, 8. 
To sum up, suffice it to say that the rise of nationalism in the Muslim world was firstly associated with the Ottoman Empire and then with foreign occupation. It was also linked to the massive attempt of political modernisation, which implied the Muslim efforts to establish the nationstate as as replacement of the Islamic caliphate system. ${ }^{16}$

\section{Muslim responses}

Muslim intellectuals, who generally gained better education domestically or abroad, were inclined to respond in the above general environment as well as their specific milieu. Ideological, political, cultural, and religious attitudes emerged and developed throughout Muslim countries in their specific context.

Language probably represented the first, most explicit, and direct impact of the encounter between Islam and the West or Europe. To meet modern political needs, new Arabic words were formed and became widely used as equivalent words for European concepts such as nation, nationalism, and patriotism. The term umma Misriyya, for example, referring to the Egyptian nation, first introduced by Napoleon, came into wide use. ${ }^{17}$ So did terms such as qawm and qawmiyyah, watan and wataniyyah, jins and jinsiyyah, and so forth. Hence, political language of Islam emerged and developed.

${ }^{16}$ Further research is needed to compare emergence of nationalism in the Muslim World and Western countries. Abdullah al-Ahsan claimed that Muslim and Western nationalism were in general different from each other, while Robert W. Hefner, for example, claimed that there were similarilities between the two, saying that religious ideals have also played a key role in many twentieth century nationalisms of and Democratisation in Indonesia, Oxford: Princeton University Press, 2000, 147.

${ }^{17}$ Bonaparte, in his first proclamation to the Egyptians in Alexandria at the end of Muharram 1213 A.H. stated," The Syaikhs, "ulama, qadis, and imams, must stay at their posts, and every single one of the inhabitants of the towns must remain quietly in his home. Also, prayers will go on as usual in the mosques, and all Egptians should thank Allah for ending the dominion of the Mamluks, saying aloud: "Allah perpetuate the glory of the 
For example, Sheikh Husayn al-Marsafi of al-Azhar, Cairo, in his book entitled Risalat al-Kälim al-Thaman (Treatise on the Eight Words, 1882) attempted to explain the meaning of the words which circulated as reformist vocabulary of the period such as watan (fatherland), umma (nation), ḥukuma (government), adl (justice), zulm (injustice), siyāsa (politics), tarbiyya (education), and hurriyya (freedom). ${ }^{18}$

The concept of the European nation has clearly affected the AraboIslamic concept of umma, watan, and jins. The umma, according to alMarsafi, "is a collectivity of people who are brought together by a unifying factor, this being, on the basis of investigation, language, locality, or religion." ${ }^{19}$ To al-Marsafi, the bond of language was the stronger one, for it enabled people to express the same ideas and, thus, to reach their communal goals. As for the word watan, al-Marsafi explained, "it is the portion of the earth inhabited by the umma" ${ }^{20}$ The term jins was used to refer to race, species, or folk. He said, "We see that the individuals of every race (jins) in Europe are bound to one another as closely as members of a single family, even if loyalties ( $a h w a$ ) are divided among political affiliations and religious sects." 21

Furthermore, Rifa'ah Rafi Al-Tahtawi (1801-1873) used the term umma and milla interchangeably. Al-Tahtawi said,"It has been established that the French nation (al-millah al-Faransiyya) is outstanding among the Western nations (al-umam al-Ifranjiyya) for the amplitude of her learning in both applied and theoretical science." On the other hand, he used milla

French army! Allah curses the Mamluks and improves the state of the Egyptian nation (alumma al-Mishriyya). Charles Wendell, The Evolution of the Egyptian National Image: From its Origins toAhmad Lutfi al-Sayyid, London: University of California Press, 1972, 90.

${ }^{18}$ Charles Wendell, The Evolution of the Egyptian National Image..., 90.

${ }^{19}$ Albert Hourani, Arabic Thought in the Liberal Age 1798-1939, London: Oxford University Press, 1970, 194.

${ }^{20}$ Charles Wendell, The Evolution of the Egyptian National Image...,.90, 138

${ }^{21}$ Charles Wendell, The Evolution of the Egyptian National Image..., 149. 
to refer to religion or sect. "They (the French) recognise the Pope, who is the King of Rome, as the supreme lord ('azim) of the Christians, and the head of their religion (kabir millatihim)". ${ }^{22}$

Jamal al-Din Al-Afghani (1839-1897) emphasises the umma Islamiyya, to serve his pan-Islamism, even though he also employed umma, qawm, milla, and sha'b. He used jinsiyyah as similar to al-qawmiyyah to mean regional nationalism. His attitudes of local patriotism and nationalism could hardly have been more apparent, however. Using the term umma, his main concern was Muslims in general, rather than the local nation, Egypt, despite the fact that his effort was to get rid of the British. ${ }^{23}$

Muhammad Abduh (1849-1905) used the term watan to mean country. Abduh encouraged the Egyptians to love his watan from all standpoints. First of all, Egypt is their place of residence. Second, it is the locale to which they can trace their origin without finding anything shameful or blameworthy in this. And finally, it is the place where they possess both rights and obligations which fall to them. ${ }^{24}$

Amir Shakib Arsalan (1869-1946), like al-Afghani, was inclined to use the vocabulary of political Arabism in the religious context. Arsalan intended the term umma more as the community of believers (even if confined to the community of Arab believers) than as a secular nation. Arsalan also used the terms al-älam al-Islamy (the Islamic world) or al-bilàd al-Islāmy (the Islamic countries). In addition, he used al-wahdah al-Arabiyya to mean an Arab unity in terms of religion, language, culture, and society, not in terms of politics. ${ }^{25}$

${ }^{22}$ Charles Wendell, The Evolution of the Egyptian National Image..., 123-6.

${ }^{23}$ Charles Wendell, The Evolution of the Egyptian National Image...,178-9, Nikki R. Keddie, an Islamic Response to Imperialism: Political and Religious Writings of Sayyid Jamal ad-Din 'alAfghani', London: University of California Press, 1983, 66.

${ }^{24}$ Charles Wendell, The Evolution of the Egyptian National Image..., 194.

25 William L.Cleveland, Islam against the West: Shakib Arsalan and the Campaign for Islamic Nationalism, London: Alsaqi Books, 1985, 128. 
Apart from linguistic responses, there were ideological responses. Several ideologies sprung into existence and competed with each other. PanArabism, regional nationalism, or Islamism, emerged and tried to appeal to people in the Middle East throughout the late nineteenth and twentieth century. As many scholars have pointed out, pan-Arabism proved to be the most enduring and compelling ideology in the period. ${ }^{26}$ From ethno-linguistic point of view, three major forms of nationalism arose in the Muslim Middle East before World War I: Persian nationalism, Turkish nationalism, and Arab nationalism. ${ }^{27}$

Contact with foreign ways prompted Muslims to respond. In terms of the relationship between authenticity and modernity, such unavoidable contact seemed to have brought about the total adoption of foreign ideas by some Muslims on the one hand, and total rejection on the other. In the middle, however, there were concessions and compromises in the thought and practice of the Muslim polity. ${ }^{28}$ This middle path seemed to become the central tendency in the Muslim world during the nineteenth and twentieth century, even though they differed from each other on the precise terms of its organisation and ideology. ${ }^{29}$

${ }^{26}$ John L.Esposito, Islam and Politics, New York: Syracuse University Press, 1984, 70.

${ }^{27}$ Majid Khadduri further urged that 'the three nationalisms were manifestations of failure of the ecumenical Islamic society to hold its own in the face of European ascendancy." See Majid Khadduri, Political Trends in the Arab World: The Role of Ideas and Ideals in Politics, London: The Johns Hopkins Press, 1970, $26-7$.

${ }^{28}$ Charles R.Watson, 'Nationality and Islam'..., 120.

${ }^{29}$ However, there were those in India who urged that any form of nationalism was antithetical to Islam. One of non-compromist ideologue is Abu Ala Al-Maududi (19031979), an Indian Muslim, who sharply constrasted the ideals and values of Islam vis-a-vis nationalism. Al-Maududi claimed that nationalism must have denied international humanity and should have given preference to his nationality over all other nationalities, whereas Islam always addressed all humanity. Moreover, nationalism, he argued, is confined to one national people, which tend to create hostility towards other peoples. Furthermore, nationalism was always imposed by force, while Islam stressed moral conduct. Nationalism and Islam therefore could never coexist. Abu "Ala al-Maududi, "Nationalism and Islam", in John J. Donohue and John L. Esposito (eds.), Islam in Transition: Muslim Perspectives. New 
The major tendency during the 19th and the early 20th centuries was perhaps an encouragement to adopt European concepts and practices, either completely or selectively. There was largely a call for an imitation of Europe, which was regarded as the only sensible way for survival and solving the problems of the Muslim disintegration and backwardness. An Egyptian scholar, Muhammad al-Attar (1766- 1835) for example, contended that since Muslims were backward, they had no option but to imitate Europe. Al-Attar was particularly impressed by the advancement of Europe. Therefore, "Our countries must change", al-Attar urged, "and we must take from Europe all the sciences which do not exist here." ${ }^{30}$ Al-Attar began to became aware of the European ideas.

An awareness of the European ideas also arose in a few Egyptians. AlTahtawi and the Ottoman tanzimat reformers were obviously interested in European civilisation. ${ }^{31}$ One of the reasons was perhaps the usefulness of European ideas and practices for the advancement of Egyptian people and Muslims. Here the reason appeared to be more pragmatical. AlTahtawi, however, did not approve of borrowing anything which contradicted the Muslim belief and law. ${ }^{32}$

Ahmad Lutfi al-Sayyid (1872-1963), later known as one of the pioneers of Egyptian nationalism, advocated importing the fundamentals of European civilisation. Yet, it was crucial for Egyptians to control the process of civilisation. What was important for Egypt to learn from Europe was the system of philosophical ideas which underlie western modern progress. ${ }^{33}$

York: Oxford University Press, 1982, 94-7; James P.Piscatori, Islam in A World of NationStates, Cambridge: Cambridge University Press, 1986, 149-50.

${ }^{30}$ Jamal Mohammed Ahmed, The Intellectual Origins of Egyptian Nationalism, London: Oxford University Press, 1960, 5.

${ }^{31}$ C.Ernest Dawn, From Ottomanism to Arabism: Essays on the Origins of Arab nationalism, U.S.A.: University of Illinois Press, 1973, 125.

32 C.Ernest Dawn, From Ottomanism to Arabism..., 127.

${ }^{33}$ C.Ernest Dawn, From Ottomanism to Arabism..., 97. 
Lutfi appeared to advocate a more selective borrowing.

Taha Husayn (1889-1973) in his book Future of Culture in Egypt (1938) argued that Egypt was, and should be, Western rather than Eastern in its cultural character. The Egyptians had to adopt European culture, because the Egyptians had already followed them step by step in almost all aspects of their public life: economy, culture, administration, law and education. This adoption is also necessary because, Husayn maintained, "the Europeans borrowed methods that prevailed in the Islamic world during the Middle Ages." ${ }^{34}$ However, Husayn went to qualify, "I am pleading for a selective approach to European culture, not wholesome and indiscriminate borrowing." ${ }^{35}$

Husayn, however, seemed not to clarify which parts of Western culture that could be borrowed and which parts of Islamic doctrines and traditions that should be maintained. Instead, Husayn seemed to recognise that secularisation process had taken place in Egypt step by step so that there was no reason for impeding further Western modernisation. After explaining the reasons, Husayn urged," the dominant and undeniable fact of our times is that day by day we are drawing closer to Europe and becoming an integral part of her, literally and figuratively. This process would be much more difficult than it is if the Egyptian mind were basically different from the European." ${ }^{36}$

A selective attitude towards European ideas was equally shown by Muhammad Rashid Rida (1865-1935), a Syrian-born intellectual. Wellknown as a conservative Islamist (salafy) ${ }^{37}$, Rida did not reject all European

${ }^{34}$ Husayn, "The Future of Culture in Egypt"..., 77.

${ }^{35}$ Husayn, "The Future of Culture in Egypt"..., 77.

${ }^{36}$ Husayn, "The Future of Culture in Egypt"..., 77.

37 The word salaf (ancestor) indicates a return to the ways of the Prophet and his companions as well as the rigtly guided caliphs, when Islam was in its pure state and Arab caliphate in the heyday of its glory. See Sylvia Haim, Arab Nationalism: An Anthology, Los Angeles: University California Press, 1962, 21. 
practices, while advocating the revival of the Islamic caliphate. In his book Khilafah, Rida proposed a selective borrowing, by recognising European administrative organisation which suited religious law and did not contradict according to the peoples. ${ }^{38}$

Hasan al-Banna (1906-1949), an Egyptian founder of al-Ikhwan alMuslimun, or Muslim Brotherhood, rejected Western colonialism and missionary activities, but was ready to accept its necessary material civilisation. ${ }^{39}$ To al-Banna, since most Muslims were religiously uneducated, then there was something to learn from good Western practices, such as its primary religious education. ${ }^{40}$

Specifically regarding patriotism and nationalism, a recognition of their existence was common. Among the first famous intellectuals was alTahtawi, who was particularly impressed by the idea of French patriotism. In depicting the progress of France, he remarked,"Without the astronomy of the people of Paris, their wisdom, their accomplishments, their good administration, and their concern with the interests of their land, their city would be nothing at all." ${ }^{\prime 1}$ He then wrote patriotic poems about Egypt.

Muhammad Abduh did not neglect the idea of nationhood. Abduh used umma to refer to the English 'nation'. Abduh identified himself as part of an Egyptian nation. Abduh said,"Yes, I was one of those who called on the Egyptian nation (al-umma al-Misriyya) to find out what her rights were..." ${ }^{42}$ Abduh never ceased to be an Egyptian. Abduh asserted that the people of Egypt (ahl Misr) were united by blood and had a dis-

\footnotetext{
${ }^{38}$ Muhammad Rashid Rida, Le Califat dans le Doctrine de Rasid Rida, trans. Henri Laoust, Beirut: n.p., 1938, 201.

${ }^{39}$ Ibrahim M. Abu Rabi, Intellectual Origins of Islamic Resurgence in the Modern Arab World, Albany: State University of New York Press, 1996, 80.

${ }^{40}$ Ibrahim M. Abu Rabi, Intellectual Origins of Islamic Resurgence..., 80.

${ }^{41}$ Quoted in Dawn, C. Ernest, From Ottomanism to Arabism..., 125.

42 Wendell, Charles, The Evolution of the Egyptian National Image..., 193.
} 
tinct customs and manners which must be respected. ${ }^{43}$

Rida recognised the importance of nationalism and patriotism in the Muslim world. He also emphasised the significance of national independence. ${ }^{44}$ Rida agreed with patriotism and nationalism which were relevant to the Muslim situation.

According to Rida, Muslims are obliged to defend the non-Muslim who enters under their rule and to treat him as an equal according to the just rules of the shari'a. Rida advocated a revival of the dhimmi system, as applied by the early rightly caliphs. ${ }^{45}$

However, Rida asserted that the type of patriotism that a Muslim should subscribe to is when he or she can be a good example for the people of the homeland whatever their religious affiliation is. Furthermore, according to Rida, a Muslim should co-operate with his co-citizens in every legitimate action for independence, for developing science, virtue, force, and resources on the basis of the Islamic law of preferring the closest relations in rights and duties. The illegitimate type of patriotism is partisanship in wrong for the sake of relatives, people, or fatherland. ${ }^{46}$

Hasan al-Banna, in fact, accepted the idea of nationalism as long as it is perceived within the framework of Islam. It was the secular, Western or European form of nationalism that was alien to Islam and thus, al-

\footnotetext{
${ }^{43}$ Wendell, Charles, The Evolution of the Egyptian National Image..., 188.

${ }^{44}$ Rashid Rida was pan-Arabist since he called for unity between Egypt, Syria, and Iraq, under one leadership. Yet, his involvement in the Syrian National Party, which was found in 1918, indicates his agreement with nationalist movement. See Emad Eldin Shahin, 'Muhammad Rashid Rida's Perspectives on the West as Reflected in Al-Manar', The Muslim World, No.79 (1989): 113-132; Eliezer Tauber, 'Rashid Rida as Pan-Arabist Before World War I', The Muslim World, No.79 (1989): 102-112; Eliezer Tauber,'Rashid Rida's Political Attitude During World War I', The Muslim World, vol.85, no.1-2, (January-April 1995): 107-121, Eliezer Tauber, 'Rashid Rida and Faysal's Kingdom in Syria', The Muslim World, vol.85, no.3-4 (July-October 1995), 235-245.

45 John J. Donohue and John L. Esposito (eds.), Islam in Transition: Muslim Perspectives, New York: Oxford University Press, 1982, 57-9.

${ }^{46}$ John J. Donohue and John L. Esposito (eds.), Islam in Transition..., 57-9.
} 
Banna claimed, it had to be rejected. What is rejected by al-Banna is the secular, the narrow and the materialist nationalism, which becomes part of shirk, or polytheism. ${ }^{47}$ A Muslim should not be a secular nationalist. Instead, a Muslim should be a religious nationalist. For a Muslim, nationalism without religion is inconceivable: 'So long as wataniyya is loyalty to the country (watan), then religion is its gate, for no loyalty is possible for him who has no religion." 48

Furthermore, to clarify what he really meant, Al-Banna made a distinction between wataniyya (patriotism) and qawmiyya (nationalism) and between true and false kinds of patriotism and nationalism. Firstly, wataniyyat al-banin is the love for one's country and place of residence, driven by both nature and Islam. The Prophet Muhammad and Bilal themselves expressed their love for their home town of Mecca.

Secondly, wataniyya al-hurriyya wa alizza is the desire for independence and pride of one's own country. Thirdly, wataniyya al-fath is the desire for conquest and world domination. Fourthly, wataniyyah al-hizbiyya is the love for party-strife and the bitter hatred of one's political opponents with all its destructive consequences. It is only the latter that is the false kind of wataniyya according to al-Banna. ${ }^{49}$

As for the classification of nationalism, he divided it into five categories. First, qawmiyya al-najd is the pride of a young generation in the glory of their forefathers and the desire to equal them. Second, qawmiyya alumma is the special interest of a person in his particular group and people (qawm, nation). Third, qawmiyya al-tanzim is the realisation of the common aims of freedom and salvation achieved by the work and struggle of each individual group. These three forms are legitimate expressions of

\footnotetext{
47 Richard P. Mitchell, The Society of The Muslim Brothers, Oxford: Oxford University Press, 1968, 264.

${ }^{48}$ P. Mitchell, The Society of The Muslim Brothers..., 265.

${ }^{49}$ P. Mitchell, The Society of The Muslim Brothers..., 265.
} 
qawmiyya. The fourth type, qawmiyya al-jähiliyya is the desire to re-establish old jähiliyyat customs and to replace Islam by an exaggerated nationalism and racism. Lastly, qawmiyya al-udwān is the desire to gain dominance for one's race (jins) over all others. Al-Banna regarded qawmiyya aljāhiliyya and qawmiyya al-udwān as illegitimate and disapproved by Islam. ${ }^{50}$

Now a question arose: what kind of nationalism was accepted by them? During the period of foreign occupation, patriotism demands 'the struggle against imperialism'. It seemed natural that the first and primary struggle of Muslim thinkers and activists in colonised regions is of course anticolonialism. Al-Banna, for example, believed that the first task of Egyptian Muslims was to get rid of the British and regarded this as their religious duty. Egypt should be made independent because it was the first link in the anticipated renaissance. To al-Banna, Egypt is a part of the general Arab nation. When the Egyptians acted for Egypt, al-Banna claimed, they acted for Arabism, the East, and for Islam. ${ }^{51}$

A response to imperialism was also a main feature of al-Afghani's struggle. ${ }^{52}$ While admitting European greatness and power, due to their mastering of science, al- Afghani said that the desire to protect fatherland (watan) and nationality (jins) and the wish to defend religion and co-religionists arouse man to compete in the arena of virtues and accomplishments. ${ }^{53}$

Clearly, al-Afghani also combated the pro-British influence of Ahmad Khan and his followers in the sense that they were pro-colonialists. ${ }^{54}$ In addition, Al-Afghani directed his criticism to materialists or neicheris, including ijtimāiyyun (socialists), ishtirākiyyun (communists), and 'adamiyyun

${ }^{50}$ P. Mitchell, The Society of The Muslim Brothers...,266.

${ }^{51}$ P. Mitchell, The Society of The Muslim Brothers...,264.

${ }^{52}$ Keddie, An Islamic Response, p. 39; Keddie, Sayyid Jamal ad-Din al-Afghan: A Political Biography, London: University of California Press, 1972, 421-2.

${ }^{53}$ Keddie, An Islamic Response..., 66, 102.

${ }^{54}$ Keddie, An Islamic Response..., 160. 
(nihilists). ${ }^{55}$ If what al-Afghani meant by the neicheris included the secularists, it would be plausible to say that al-Afghani attacked secularism.

Al-Afghani maintained that a religious bond was stronger than any racial or linguistic bond. ${ }^{56}$ In his journal al-Urwah al-Wuthqa, al-Afghani maintained that the religious bond which unites Muslims was stronger than the bonds of nationality and language, so long as the Qur'an continues to be read among them..$^{57}$ In another place, al- Afghani stated,

This is the secret behind the Muslims' disregard, despite their originating from different countries, for differences of nationality, and their rejection of any group loyalty (naw' min anwa' al-așäbiyyat) apart from their loyalty to Islam. For when the believer in Islam has his faith firmly fixed within him, he forsakes his race and his people (yalhu 'an jinsihi was sha'bihi) and sloughs off particularist ties for broader attachments, these being the attachment (sic) of (shared) belief. ${ }^{58}$

Likewise, Rida clearly supported the struggle for independence and the formation of a new regime in his home country, Syria. ${ }^{59}$ According to him, colonialism never benefited the Muslim world. Muslim peoples under foreign domination had no power to collaborate with each other in order to establish the unity of the Muslim community (umma) on which the unity of leadership (imama) rests. ${ }^{60}$ Rida further condemned the im-

55 Jamal ad-din al-Afghani, Réfutation des Matérialistes, trans. A.M.Goichon, Paris: Librairie Orientaliste Paul Geuthner, 1942, 65, 136-7.

56 Jamal ad-din al-Afghani, Réfutation des Matérialistes..., 65, 136-7.

57 Wendell, Charles, The Evolution of the Egyptian National Image...,172.

${ }^{58}$ Wendell, Charles, The Evolution of the Egyptian National Image...,173.

${ }^{59}$ As a Syrian, Rashid Rida was among the advocates of the Syrian independence. As Tauber points out,"He did not abandon his Utopia of establishing the single great Arab State, or at least achieving union between rulers of the Arabian peninsula, yet in the current situation the more important task for him was to contribute to the formation of the new regime." Eliezer Tauber,'Rashid Rida and Faysal's Kingdom in Syria', The Muslim World, vol.85, no.3-4 (July-October 1995): 245.

${ }^{60}$ Rida, Muhammad Rashid, Le Califat dans le Doctrine de Rasid Rida, trans. Henri Laoust, Beirut: n.p., 1938, 97. 
perialist powers which always opposed Islamic unity and the revival of caliphate. Muslim countries therefore had to be independent in order to be able to adopt and apply Islamic law and system. Rida stated," The Muslims, in fact, consider that their religion will only exist when a Muslim state is established, independent and strong, which enabled, free from all the opposition and all the foreign domination, the application of the law of Islam." ${ }^{61}$ For Rida the struggle against imperialism was a religious obligation.

The struggle against European imperialists was also the primary preoccupation of Amir Shakib Arsalan. ${ }^{62}$ In the journal La Nation Arabe, Arsalan expressed his anti- imperialism. Independence was his goal in dealing with Europeans. ${ }^{63}$ Arsalan wrote in bitterness,

Why not despair when everyday we are subjected to shame? We look at Syria and find France clinging to it in order to transform it into a colony... We look at Iraq and find it crippled by England which grants it independence in name only. We look at Palestine and find England pouring in Jews and pouring out Arabs. We turn to Egypt and find England unwilling to grant even a limited, mutilated independence unless she receives the Sudan as outright booty. ${ }^{64}$

Besides the characteristic of anti-imperialism, the role of Islam is certainly significant for many of the Muslim intellectuals. How have they viewed Islam in their discourse of nationalism? In principle, Islam became a factor in nationalism on two levels: as a moral force and as a political ideology. Al-Nadhim, Al-Tahtawi, Lutfi al- Sayyid, al-Masrafi, Ali Abd al-Razik, Taha Husayn, and Sati al-Husri seemed inclined to place Islam as a moral force, while al-Afghani, al-Kawakibi, Rashid Rida, Shakib

\footnotetext{
${ }^{61}$ Rida, Muhammad Rashid, Le Califat dans..., 194.

${ }^{62}$ Cleveland, Islam against the West..., 66-7.

${ }^{63}$ Cleveland, Islam against the West..., 161.

${ }^{64}$ Cleveland, Islam against the West..., 66-7.
} 
Arsalan, and Hasan al-Banna, were among those who viewed Islam as a political ideology.

Al-Nadim attempted to combine the Islamic umma and the Egyptian nation. Al- Nadim seemed more concerned with the problem of survival for the entire Islamic umma than with the assertion of a self-centred 'Egyptianism'. Despite his strong feeling for the watan, al-Nadim never really stopped thinking of the world as constituted by the two dars (houses of war and house of Islam). ${ }^{65}$ According to al-Nadim, language and religion should therefore be maintained if a nation is to perpetuate like European nations do. In Egypt, al-Nadim did not see the problem of linguistic unity, but he was concerned with the problem of religious unity because the Muslims were internally in conflict. ${ }^{66}$ In the political arena, however, al-Nadim preferred a pluralist party to an Islamic one. In an article during the heyday of 'Urabi's National Party (al-Hizb al- Watani), for example, he stressed that The National Party, in which he was involved, was a political, not religious, party. ${ }^{67}$

For al-Tahtawi, Islam and the Egyptian nation could coexist. The two loyalties were not potentially and actually in conflict. ${ }^{68}$ To him, the Islamic past, Egyptian heritage, the Roman history, and the European nationstate, seem to be praiseworthy.

After mentioning, in his Manāhij al-Albāb al-Mișriyya (Methods of Egyptian Thoughts), the Prophetic saying (hadith), 'The Muslim is brother of the Muslim', al- Tahtawi maintained that there is a moral obligation for those who share the same watan to work together to improve it and make perfect its organisation in all that concerns its honour, greatness

${ }^{65}$ Wendell, Charles, The Evolution of the Egyptian National Image...,156.

${ }^{66}$ Wendell, Charles, The Evolution of the Egyptian National Image..., 157.

${ }^{67}$ Wendell, Charles, The Evolution of the Egyptian National Image...,158.

${ }^{68}$ Albert Hourani, Arabic Thought in the Liberal Age 1798-1939, London: Oxford University Press, 1970, 194. 
and wealth. ${ }^{69} \mathrm{Al}-$ Tahtawi expressed the need for his countrymen to distinguish 'brotherhood of country' from 'brotherhood of religion'. ${ }^{70}$ According to him, "Every duty that believer has towards his brother in believer is incumbent on the members of the watan in terms of the rights they may claim of one another because they share in a brotherhood of patriotism besides the brother hood of religious belief." ${ }^{11}$ Al- Tahtawi, thus, did not seem to advocate Islamic activism. Instead, he was in favour of a cultural Islam, that is to say Islam should play a role in the nationbuilding culturally, not politically.

Al-Marsafi saw the lack of religiosity as the cause of Muslim backwardness. Al-Marsafi could not feel secure in developing his concept of nationalism without first addressing the internal problem of the Muslims. According to him, the decadence of the Muslims was caused by their own fault. Religious men, government officials, and landlords did not strive to progress. The Muslims often quarrelled among themselves. ${ }^{72}$ Hence, nationalism, to al-Marsafi, cannot be developed without addressing the religious problem.

That religion in general is a moral determinant factor in nationhood can also be seen in Lutfi al-Sayyid. Lutfi disagreed with the idea of panIslamism in the political sense as well as pan-Arabism, saying that both are delusions (khayalat) and fancies (awham), and reminding the Egyptians not to make religion the basis for their political acts. ${ }^{73}$ However, he stills viewed religion as important as nationhood in forming the identity and cultural behaviour of Egyptians. For Lutfi, a religious based society is superior to a non-religious one. He encouraged nationalists to teach its peoples religions

\footnotetext{
${ }^{69}$ Albert Hourani, Arabic Thought..., 79.

70 Albert Hourani, Arabic Thought..., 79.

${ }^{71}$ Charles Wendell, The Evolution of the Egyptian National Image...,128-9.

${ }^{72}$ Charles Wendell, The Evolution of the Egyptian National Image...,136.

${ }^{73}$ Charles Wendell, The Evolution of the Egyptian National Image...,229-33.
} 
despite numerous theories of good and evil. ${ }^{74}$ Religion, to Lutfi, should be the basis of general education. ${ }^{75}$

As for the place of Islam in his concept of nationalism, Taha Husayn stated that Islam happens to be the religion of most Egyptians, which satisfies their hearts. ${ }^{76}$ In his books 'Ala Hamish al-Sira (On The Wonderful Biography, 1937-43) and al-Wa'd al-Haqq (The True Promise, 1950), Husayn demonstrates that religion in general and Islam in particular can strengthen the moral of the nation. ${ }^{77}$ It is obvious here that Husayn was more concerned with Islam as an ethical system rather than a political ideology.

Sati al-Husri (1880-1964), a Syrian born scholar, a pan-Arabist advocate par excellence, even though well-known as representing a 'secular' way of thinking, was not opposed to the idea of Islamic solidarity. ${ }^{78}$ For al-Husri, Islam was confined to Muslims in their internal social-cultural life. He said,

The idea of Muslim unity is wider and more inclusive than the concept of Arab unity, but it is not possible to advocate Muslim unity without advocating Arab unity....The expression 'unity' in this context means political unity...the concept of Islamic unity greatly differs from that of Muslim Brotherhood.... He who denies the possibility of realising Muslim unity does not deny the principle of Muslim brotherhood or oppose the efforts toward the awakening of the Muslims and understanding among them. ${ }^{79}$

In addition, Al-Husri, while advocating Arabiyya Awwalan (Arab First), did not completely neglect the importance of nationalism, i.e. national

\footnotetext{
${ }^{74}$ Albert Hourani, Arabic Thought..., 172.

${ }^{75}$ Albert Hourani, Arabic Thought..., 172; Charles Wendell, The Evolution of the Egyptian National Image..., pp.272-4.

${ }^{76}$ Charles Wendell, The Evolution of the Egyptian National Image..., 333.

${ }^{77}$ Charles Wendell, The Evolution of the Egyptian National Image..., 334.

${ }^{78}$ Charles Wendell, The Evolution of the Egyptian National Image..., 173.

${ }^{79}$ Sati al-Husri, "Muslim Unity and Arab Unity"..., 65-8.
} 
independence and unity. In his Ma Hiya Al-Qawmiyyah (What is nationalism?), for example, while stressing that language and history as the strongest bond for Arab's people, al-Husri considered national independence as a step towards a wider and stronger Arab nation. ${ }^{80}$

Likewise, well known as representing a secular variant of Muslim political thought, Ali Abd al-Razik (1888-1966) in his Al-Islām wa Ușūl alAhkām (Islam and Fundamentals of Government), did not deny the importance of Islam in the Muslim community. What Al-Razik urged was that Islamic caliphate be abolished. To al-Razik, Islam deals with more religious than political affairs. The authority of the Prophet was more spiritual than political. Hence, religion should be separated from state. ${ }^{81}$ This does not mean, however, that there is no legitimate authority in the Islamic community, ${ }^{82}$ nor that Islam as a religion should be thrown away as a moral force. What al-Razik refused to accept was the formal integration of Islamic sharia (din) and the state (daulah). He can be categorised as representing the advocate of Cultural Islam (Islam Hadary), that is to say Islam as a cultural and social force, not as a political ideo$\operatorname{logy} .{ }^{83}$

By comparison, the following intellectuals showed a more political overtone in their concept of nationalism. Abd al-Rahman al-Kawakibi (1849-1903), a Syrian, in his books Taba'i al-Istibdād (The Characteristics of Tyranny) and Umm al-Qura (Mother of the Cities), expressed his opposition to the despotism of Abd al-Hamid II and advocated an Arab-Islamic nationalism. Al-Kawakibi called for the restoration of the caliphate

\footnotetext{
${ }^{80}$ Sati al-Husri, "Muslim Unity and Arab Unity"..., 65-8.

${ }^{81}$ Ali abd al-Razik, Al-Islam wa Usul al-Ahkam, Beirut: Dar al-Maarif, 1966; Charles C.Adams, Islam and Modernism in Egypt, London: Oxford University Press, 1933, 259-68.

${ }^{82}$ Albert Hourani, Arabic Thought..., 183.

${ }^{83}$ Nazih N. Ayubi, Political Islam: Religion and Politics in the Arab World, London: Routledge, 1991, 201-2.
} 
from Turkish to Arab hands, while keeping the Ottoman unity, based on a temporal Islamic caliphate, of the line of Quraish, nominated by the Muslim rulers. ${ }^{84} \mathrm{He}$ tried to combine the idea of nation and Islam by advocating the Islamic caliphate. ${ }^{85}$ He worked out an Arab nationality while remaining an orthodox Muslim. ${ }^{86}$ Al-Kawakibi appeared to view Islam as a necessary political factor in achieving Arab unity.

Other intellectuals also stressed Islam as a political ideology. Al-Afghani has been regarded as a key ideologue of pan-Islamism in modern times. Al-Afghani viewed Islam as a tool for a political struggle. ${ }^{87}$ His concept of nationalism cannot be regarded as secular. From his writings and activities, it can be clearly seen that Afghani placed Islam as paramount to everything else. Al-Afghani, for example, maintained that religion is the mainstay of nations and the source of welfare. ${ }^{88}$ However, while al-Afghani called for an Islamic unity, he seemed not to advocate an Islamic state. ${ }^{89}$

Rashid Rida clearly demonstrated how Islam should be the most important factor in nationhood. While considering nationalism as something natural, he contended that Islam should not be neglected because a Muslim is a member of a body greater than his people and his homeland..$^{90}$ Rida proposed an Islamic State in the form of caliphate. Islam was not merely a moral element but a political force which enabled Muslims to live with their own system of law and government. To Rida, na-

\footnotetext{
${ }^{84}$ Albert Hourani, Arabic Thought..., 271-3; Majid Khadduri, Political Trends in the Arab World: The Role of Ideas and Ideals in Politics, London: The Johns Hopkins Press, 1970, 16, 32.

${ }^{85}$ Bassam Tibi, Arab Nationalism: Between Islam and the Nation-State, London: Macmillan Press Ltd, 1997, 163.

${ }^{86}$ Sylvia Haim, "Islam and the Theory of Arab nationalism"..., 170.

${ }^{87}$ See Nikki R. Keddie, An Islamic Response..., 97.

${ }^{88}$ Nikki R. Keddie, An Islamic Response..., 130.

${ }^{89}$ Sati al-Husri, Ma Hiya al-Qawmiyyah..., 77-83.

${ }^{90}$ In Donohue and Esposito (eds.), Islam in Transition: Muslim Perspectives, New York: Oxford University Press, 1982, 57-9.
} 
tionhood is inconceivable without Islam as its primary political dimension.

Like Rida, Arsalan was an Islamic nationalist who saw in the Islamic umma a weapon with which political independence could be achieved. ${ }^{91}$ Arsalan, in his limädha taakhara al-Muslimūn wa taqaddam al-äkharün (why are the Muslims backward while Others are advanced?) insisted, "Have confidence in yourselves, be good Muslims, and remain united in your struggle to reclaim your rights!"92 Arsalan saw the need to establish a Muslim state. Here Islam became a political ideology. ${ }^{93}$

It is worth noting that, in the attempt at a compromise, some of the Muslim intellectuals dealt with the problem of ethics of nationalism. AlAfghani, Abduh, and Rida were among those who reminded Muslim nationalists of the possible excess of fanaticism, which may led to hostility, injustice, and narrow-mindedness, and can destroy the Muslim umma. ${ }^{94}$

In brief, despite differences in articulation and emphasis, the bestknown of Egyptian and Syrian Muslim intellectuals recognised the adoption of foreign ideas and importance of nationalism, while viewing Islam as an ethical force, if not a political one.

\section{Conclusion}

As a response to the Ottoman power, foreign occupation, and the related challenge of political secularisation, the question of nationalism and Islam became the focus of concern of many leading Egyptian and Syrian Muslim intellectuals during the nineteenth and first half of the

${ }^{91}$ Cleveland, Islam against the West..., 160-1.

92 Cleveland, Islam against the West..., 160-1.

${ }_{93}$ Cleveland, Islam against the West..., 20-1.

${ }^{94}$ Charles Wendell, The Evolution of the Egyptian National Image..., 198-9, 233; Sati alHusri, Ma Hiya al-Qawmiyyah, Beirut: Markaz Dirasat al-Wahda al-Arabiyya, 1985, 188; Malcom H. Kerr, Islamic Reform: The Political and Legal Theories of Muhammad Abduh and Rashid Rida, Berkeley and Los Angeles: University of California Press, 1966, 138. 
twentieth century. ${ }^{95}$ However various the solutions they proposed, one can see a major tendency that a Muslim could accept certain aspects of foreign ideas which are relevant and useful.

In the process of reconciliation, nationalism has led to the redefinition of Islam in the socio-political term: whether or not Islam was compatible with foreign ideas, including nationalism and whether Islam is seen as a political ideology or as a moral system. On the other hand, the recognition of Islam has affected the nature and face of nationalism in the region. The account that nationalism must not be entirely secular represented the influence of Islam. In other words, although nationalism is originally Western and secular, its significance was recognised, as far as it did not contradict to Islam. In this regard, a compromise between 'authenticity' (Islam) and 'modernity' (nationalism) was to work out.

Thus, the concern of most of them was directed toward adopting European political systems selectively and toward asserting Islam as a religion in harmony with modernity. In this view, Islamic umma, or Muslim community, which embraces all of humanity and is subject to God's authority, can not be simply superseded by national identity and loyalty. The dichotomy between nationalism and Islam was not existent when a compromise can be worked out in the form of what one may call a 'religious or Islamic nationalism'.

The Muslim discourse of nationalism and Islam has at least demonstrated that, in response to any foreign ideas and practices, neither total rejection nor blind adoption was relevant for the Muslims. A dialogue

\footnotetext{
${ }^{95}$ Secularisation had several levels. At its minimum, it is the decline of the prestige and power of religious teachers, ending of state support for religious bodies, of religious teaching in national schools, or legislative protection for religious doctrines. At the midlevel, it is the decline of widespread interest in religious traditions. At its maximum, it is the end of all interest in religious questions and attitudes. See Allan Bullock and Stephen Trombley (eds.), A New Fontana Dictionary of Modern Thought..., 778-9, Roger Scruton, A Dictionary of Political Thought..., 498.
} 
between Islam and the West, thus, can be promoted through a proper historical understanding of the relations between the Muslims and the West, one example of which occurred in the nineteenth and the twentieth century's Middle East.

\section{Bibliography}

Adams, Charles C. Islam and Modernism in Egypt. London: Oxford University Press, 1933.

Afghani, Jamal ad-din al. Refutation des Matérialistes, trans. A.M.Goichon. Paris: Librairie Orientaliste Paul Geuthner, 1942.

Ahmed, Jamal Mohammed. The Intellectual Origins of Egyptian Nationalism. London: Oxford University Press, 1960.

Ahsan, Abdullah. Ummah or Nation: Identity Crisis in Contemporary Muslim Society. Wiltshire: Cromwell Press Ltd., 1992.

Ayubi, Nazih N. Political Islam: Religion and Politics in the Arab World. London: Routledge, 1991.

Bullock, Allan and Stephen Trombley (eds.). A New Fontana Dictionary of Modern Thought. London: HarperCollins Publishers, 1999.

Cleveland, William L. A History of the Modern Middle East. Colorado: Westview Press, Inc., 1994.

Cleveland, William L. Islam Against the West: Shakib Arsalan and the Campaign for Islamic Nationalism. London: Alsaqi Books, 1985.

Cleveland, William L. The Making of An Arab Nationalist: Ottomanism and Arabism in the Life and Thought of Sati al-Husri. Princeton: Princeton University Press, 1971.

Dawn, C. Ernest. From Ottomanism to Arabism: Essays on the Origins of Arab Nationalism. U.S.A.: University of Illinois Press, 1973. 
Donohue John J. and John L. Esposito (eds.). Islam in Transition: Muslim Perspectives. New York: Oxford University Press, 1982.

Emerson, Rupert. From Empire to Nation: The Rise of Self-Assertion of Asian and African Peoples. Cambridge: Harvard University Press, 1960.

Esposito, John L. Islam and Politics. New York: Syracuse University Press, 1984. Haim, Sylvia. Arab Nationalism: An Anthology. Los Angeles: University California Press, 1962.

Halliday, Fred. Nation and Religion in the Middle East. London: Alsaqi Books, 2000.

Halliday, Fred, "The perils of community: reason and unreason in nationalist ideology", Nations and Nationalism 6 (2), (2000).

Hefner, Robert W. Civil Islam: Muslims and Democratisation in Indonesia. Oxford: Princeton University Press, 2000.

Heywood, Andrew. Politics. Basingstoke: Macmillan, 1997.

Hourani, Albert. Arabic Thought in the Liberal Age 1798-1939. London: Oxford University Press, 1970.

Husri, Sati al-.Ma Hiya al-Qawmiyyah. Beirut: Markaz Dirasat al-Wahda alArabiyya, 1985.

Jankowski, James and Israel Gersoni (eds.). Rethinking Nationalism in the Arab Middle East. (New York: Colombia University Press, 1997.

Karpat, Kemal H. (ed.). Political and Social Thought in the Contemporary Middle East. London: Frederick A. Praeger, Inc., 1968.

Keddie, Nikki R. An Islamic Response to Imperialism: Political and Religious Writings of Sayyid Jamal ad-Din 'al-Afghani'. London: University of California Press, 1983.

Kerr, Malcom H. Islamic Reform: The Political and Legal Theories of Muhammad Abduh and Rashid Rida. Berkeley and Los Angeles: University of California Press, 1966. 
IJIMS, Indonesian Journal of Islam and Muslim Societies, Volume 4, Number 1, June 2014: 51-79

Khadduri, Majid. Political Trends in the Arab World: The Role of Ideas and Ideals in Politics. London: The Johns Hopkins Press, 1970.

Mitchell, Richard P. The Society of the Muslim Brothers. Oxford: Oxford University Press, 1968.

Murray, James A.H. (ed.). A New English Dictionary on Historical Principles, vol. 4, part 1 (1901).

Philpott, Daniel, “The Religious Roots of Modern International Relations”, World Politics 52 (January 2000).

Piscatori, James P. Islam in A World of Nation-States. Cambridge: Cambridge University Press, 1986.

Rabi, Ibrahim M.Abu. Intellectual Origins of Islamic Resurgence in the Modern Arab World. Albany: State University of New York Press, 1996.

Rida, Muhammad Rashid. Le Califat dans le Doctrine de Rasid Rida, trans. Henri Laoust. Beirut: n.p., 1938.

Razik, Ali abd al-. Al-Islām wa Ușūl al-Ahkām. Beirut: Dar al-Maarif, 1966. Scruton, Roger. A Dictionary of Political Thought. London: Macmillan, 1996.

Shahin, Emad Eldin, "Muhammad Rashid Rida's Perspectives on the West as Reflected in Al-Manar”, The Muslim World, vol.79 (1989).

Smith, Charles D., "Secularism", in John L.Esposito (eds.) The Oxford Encyclopedia of the Modern Islamic World. Oxford: Oxford University Press, 1995.

Tauber, Eliezer, "Rashid Rida as Pan-Arabist Before World War I", The Muslim World, vol. 79 (1989)

Tauber, Eliezer, "Rashid Rida's Political Attitude during World War I", The Muslim World, vol.85, no.1-2, (January-April 1995).

Tauber, Eliezer, "Rashid Rida and Faysal's Kingdom in Syria”, The Muslim World, vol.85, no.3-4 (July-October 1995). 
Nationalism and Islam: perspective of Egyptian and Syrian Muslim intellectuals (Muhamad Ali)

Tibi, Bassam. Arab Nationalism: Between Islam and the Nation-State. London: Macmillan Press Ltd., 1997.

Tutsch, Hans E. Facets of Arab Nationalism. Michigan: Wayne State University Press, 1965.

Watson, Charles R., 'Nationality and Islam', The Muslim World, vol. XVI, no.2, (1926). Wendell, Charles. The Evolution of the Egyptian National Image: From its Origins to Ahmad Lutfi al-Sayyid. London: University of California Press, 1972. 